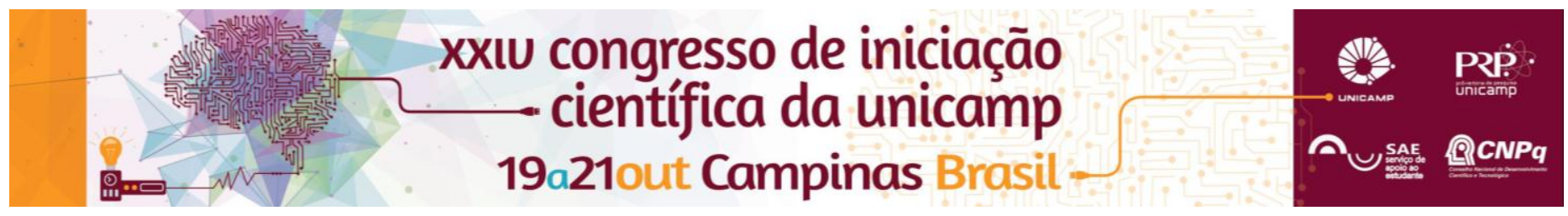

\title{
O gênio artista: uma discussão a partir da psicologia histórico-cultural
}

\section{Klesley B. Brandão*}

\begin{abstract}
Resumo
O estudo acerca das construções históricas referentes ao Talento são importantes para a area da educação musical. Por intermédio de cuidadosa revisão bibliográfica, buscou-se analisar o conceito de Talento segundo a perspectiva do filósofo Immanuel Kant (1724-1804), do educador musical Shinichi Suzuki (1898-1998) e do psicólogo Lev Semionovitch Vigotski (1896-1934). Conclui-se que o talento musical não pode ser completamente inato, entretanto não ocorre apenas mediante a um contato com determinado meio, mas sim é produto do entrelaçamento dialético de fatores biológicos e culturais. A compreensão dessa ultima assertiva contribui para a busca de práticas pedagógicas mais eficientes para o campo da educação musical.
\end{abstract}

\section{Palavras-chave:}

Talento, inatismo, psicologia histórico-cultural

\section{Introdução}

A presente pesquisa propôs-se a investigar o talento artístico sob o prisma de três autores de distintas áreas do conhecimento que abordaram essa questão em diferentes perspectivas: o filósofo Immanuel Kant numa abordagem inatista; Shinichi Suzuki numa perspectiva empirista; e Lev S. Vigotski ancorado na psicologia histórico-cultural. Os dois primeiros autores foram escolhidos não apenas por serem representantes de duas tendências opostas, mas, sobretudo, por terem influenciado direta ou indiretamente 0 pensamento educacional da música. A psicologia histórico-cultural, aqui representada por Vigotski, por sua vez, foi trazida por apresentar uma visão mais integradora e promissora em relação às questões colocadas neste trabalho.

\section{Resultados e Discussão}

Kant considerava que o conhecimento é oriundo da experiência, mas que só é possível o homem adquirir esse conhecimento por que o sujeito traz consigo suas faculdades apriorísticas de sensibilidade e entendimento. Porém ao que se refere a talento artístico, que no campo musical podemos traduzir como musicalidade, Kant considera que não é possível ser ensinado. De acordo com esse filósofo, as habilidades que uma pessoa artisticamente talentosa é capaz de desenvolver, o indivíduo genial já as traz consigo desde o nascimento.

Suzuki representa uma importante ruptura com a perspectiva inatista no que tange ao talento musical. Para esse autor, qualquer criança pode desenvolver talento e se tornar genial, sendo para isso apenas necessário, um treinamento adequado.

Entretanto, partindo da premissa de que o fazer musical depende das funções psicológicas superiores características do ser humano, pressupostos empiristas não dão conta de contemplar todas as facetas da performance musical, sobre tudo da criatividade e do desenvolvimento da expressividade musical.

A temática referente ao talento é de relevante importância para área da educação musical, pois a depender da crença de determinado educador, acerca da proveniência do talento, alunos podem ser prejudicados.

A investigação aqui realizada demonstra que de acordo com a psicologia histórico-cultural, os fatores inatos não são suficientes para determinar quais as capacidades e atividades que o indivíduo terá condições de desenvolver e realizar em níveis excelentes. Dessa maneira, essa abordagem acaba refutando 0 ideal kantiano de talento inato personificado no gênio artista, ideal este que exerceu grande influência no século XIX, período este que forneceu grande parte do repertório estudado nas instituições de ensino musical. $O$ ideal de talento como algo inato ainda apresenta fortes reminiscências em nossa atual sociedade. Contudo é importante salientar que Vigotski não desconsidera os fatores inatos, para o autor o fator genético-biológico é apenas um ponto de partida.

\section{Conclusões}

A respeito do fazer musical, podemos concluir que essa é uma atividade humana dependente das funções psicológicas superiores, e sendo essas desenvolvidas ao longo do processo de apropriação da experiência social da história de cada indivíduo, não se encontram prontas desde o nascimento. $O$ que, de acordo com a perspectiva histórico-cultural, não significa que apenas a presença do individuo em determinado meio musical seja suficiente para esse desenvolver sua musicalidade.

Nesse sentido, conclui-se que para uma prática pedagógica musical eficiente se faz imprescindível entender que as funções psicológicas superiores são fundamentalmente mediadas e se desenvolvem porque os seres humanos vivem em sociedade partilhando uma cultura. Ou seja, para a abordagem histórico-cultural, o psiquismo do homem é constituído a partir do entrelaçamento dialético do biológico com o cultural. Assim sendo, o papel do professor de música enquanto mediador é de extrema importância no desenvolvimento musical do educando.

\section{PIBIC/CAPES}

\section{Agradecimentos}

KANT, Immanuel. Crítica da faculdade do juízo. Tradução de Valério Rodhen e António Marques. $3^{\text {a }}$ ed. Rio de Janeiro: Forense Universitária, 2012.

SUZUKI, Shinichi. Educação é amor: um novo método de Educação. Tradução para o Português, Anne Corinna Gottberg. $3^{\mathrm{a}}$ ed. Santa Maria: Pallotti, 2008. VYGOTSKY, Lev Semyonovich; LURIA, Alexander Romanovich. Estudos sobre a história do comportamento: Estudos sobre a história do comportamento símios, homem primitivo e criança. Porto Alegre: Artes Médicas, 1996. 